\title{
High-Yielding and Carotenoid-Rich Clones Identification among Thirty-One Cassava Clones with Colored Flesh
}

\section{N’Zue Boni' ${ }^{1}$, Coulibaly Idriss Koudous ${ }^{2}$, Koffi Kouamé Guillaume ${ }^{2 *}$, Essis Brice Sidoine1, Dibi Konan Evrard Brice1, Sie Raoul Sylvère ${ }^{2}$}

${ }^{1}$ Centre National de Recherche Agronomique (CNRA), Baouké, Côte d'Ivoire

${ }^{2}$ Université Nangui Abrogoua, UFR Sciences de la Nature, Unité de Phytotechnie et Amélioration Génétique, Abidjan 02, Côte d'Ivoire

Email: *koffiguillaume2005@yahoo.fr

How to cite this paper: Boni, N., Koudous, C.I., Guillaume, K.K., Sidoine, E.B., Brice, D.K.E. and Sylvère, S.R. (2021) High-Yielding and Carotenoid-Rich Clones Identification among Thirty-One Cassava Clones with Colored Fles. American Journal of Plant Sciences, 12, 1445-1458.

https://doi.org/10.4236/ajps.2021.129102

Received: July 31, 2021

Accepted: September 23, 2021

Published: September 26, 2021

Copyright $\odot 2021$ by author(s) and Scientific Research Publishing Inc. This work is licensed under the Creative Commons Attribution International License (CC BY 4.0).

http://creativecommons.org/licenses/by/4.0/

(c) (i) Open Access

\begin{abstract}
Cassava is the second most important food crop produced and consumed in Côte d'Ivoire, after yam. White-fleshed varieties, which are low in total carotenoids, are widespread, while coloured-fleshed varieties (yellow to orange), carotenoid-rich, are rare. However, the consumption of carotenoid-rich cassava varieties could help to alleviate health problems related to vitamin A deficiency. This study aims to identify high agronomic performance, carotenoid-rich and versatile cassava varieties among 31 clones introduced from IITA. They were compared to three controls, Bocou2, Yacé and Bonou2, according to agronomic and technological parameters. Results found that out of the 31 clones, six (I082425, I084157, I084563, I085894, I083774 and I070520) were more productive than the control Bocou2 $\left(46.01 \pm 14.88 \mathrm{t} \cdot \mathrm{ha}^{-1}\right)$; the clone I083774 had the highest yield $\left(55.88 \pm 6.16 \mathrm{t} \cdot \mathrm{ha}^{-1}\right)$. Twenty-one clones had dry matter contents, ranging from $37 \%$ to $41 \%$, significantly similar to Yacé control $(42.70 \%)$. Thirteen clones had highest total carotenoid contents than the control Bocou2. Clones I084157 and I082425 recorded the highest total carotenoid contents with $17.57 \pm 1.92$ and $18.39 \pm 1.19 \mu \mathrm{g} \cdot \mathrm{g}^{-1}$ respectively. Overall 31 tested clones were fibrous to varying degrees while 27 clones had mild or neutral post-cooking flavours and 17 clones had poor cooking. The clone $\mathrm{I} 084157$ is the best compromise of agronomic and technological desired traits.
\end{abstract}

\section{Keywords}

Manihot esculenta, Carotenoid-Rich, Coloured-Flesh Cassava, High Yied, Provitamin A 


\section{Introduction}

Cassava is one of the main food crops in tropical regions with annual world production of $277,808,759$ tons in 2019 [1], of which $169,673,737$ tons, or $61.1 \%$ of this production, is in Africa. Cassava is a perennial plant, mainly cultivated for its starchy tuberous roots [2]. It is a food and industrial commodity that plays a very important role in food security and in the textile industry [3]. Cassava is the second largest source of food energy in some African countries where malnutrition problems are recurrent [4].

In Côte d'Ivoire, most of cassava is produced in the southern half of the country even if it's grown in all regions [5]. In 2017, Ivorian cassava production was $5,000,667$ tons [1] and was the second largest food crop after yam. As a staple food in Côte d'Ivoire, this crop is well integrated into several cropping systems. There are many derivatives (cassava semolina, placali, foutou, flour, starch, gari, etc.) and they are the object of internal trade, in the sub-region [5] and outside Africa [6].

However, producers and consumers' requirements (high yield, high dry matter content, starch quality and content, multipurpose uses) remain a challenge. In addition, most cultivated varieties are white or cream-flesh, with tuberous roots generally containing very few carotenoids [7]. Cassava varieties with coloured flesh potentially rich in carotenoids are very poorly available and not well known by the population. Beta-carotene carotenoids are essential for the performance of multiple functions (normal functioning of vision and the immune system, growth and development, maintenance of epithelial cell integrity and reproduction) by vitamin A in humans. Vitamin A deficiency is the leading cause of blindness in children and increases the risk of cancer, stunted growth in young people, various diseases and even death [8]. To limit these constraints and health problems, the selection and production of cassava varieties rich in provitamin A, with high agronomic and technological interest are needful. To this end, a lot of work has been conducted at national and international level ([9] [10] [11] etc.). Thus, high yielding coloured flesh cassava varieties with high carotenoid content have been identified. In 2014, CNRA, through its Root and Tuber Plant (RTP) program, introduced from IITA Ibadan new coloured flesh cassava clones under selection. An evaluation of the performance of these new coloured flesh cassava clones successively in stations and in farmers' environment is therefore essential. The aim of this study is triple; to identify high-yielding, carotenoid-rich and versatile cassava varieties.

\section{Material and Methods}

\subsection{Plant Material}

The material consisted of 31 IITA coloured flesh clones and 3 control varieties (Yacé, Bonoua2 and Bocou2). Bocou2 is a new improved variety introduced from IITA and selected by CNRA after a series of multi-local evaluations. It is yellow-flesh and good production potential (yields of around $32 \mathrm{t} \cdot \mathrm{ha}^{-1}$ in station) 
and use in semolina. Yace is a white-flesh cultivar that is widespread in the southern region around Abidjan and is used in the manufacture of semolina and placali. It has a root production level of $25 \mathrm{t} \cdot \mathrm{ha}^{-1}$ in station and a dry matter content $(40 \%)$ that is appreciated by users. Bonoua2 (20 th ha $\mathrm{a}^{-1}$ in station), a white-flesh cultivar, is widespread in the western region of Côte d'Ivoire and is used for the preparation of stew and foutou. It is sweet and has good culinary ability in water. The three varieties served as reference controls for yield and total carotenoid content (Bocou2), for dry matter content (Yacé), for taste and cooking (Bonoua2).

\subsection{Study Site}

The study was conducted at the CNRA's Station de Recherche sur les Cultures Vivrières (SRCV) in Bouaké $\left(7^{\circ} 4^{\prime} \mathrm{N}\right.$ and $\left.5^{\circ} 2^{\prime} \mathrm{W}\right)$, central Côte d'Ivoire, in the Guinean savannah (Figure 1), where moderately desaturated ferralitic soils dominate. The rainfall regime is limited to two rainy seasons (April to July and September to October) and two dry seasons (August and November to March). The average annual rainfall is between 1100 and $1200 \mathrm{~mm}$. The average temperature is $25.73^{\circ} \mathrm{C}$ [12] and the annual insolation duration is $2200 \mathrm{~h}$ [13].

\subsection{Experimental Design}

The assay was conducted in three replicates using the Lattice design. Each replication consisted of two blocks of 17 elementary plots that received 34 genotypes. Each plot had four lines of six plants. Spacing was $0.8 \mathrm{~m}$ between plants, $0.8 \mathrm{~m}$ between rows, $1.5 \mathrm{~m}$ between plots and $2 \mathrm{~m}$ between blocks. The land was cleared and machine plowed. The cuttings were planted horizontally to a depth at less than $10 \mathrm{~cm}$. Maintenance consisted of replacing missing plants one month after planting and weeding. Subsequently, weeding was done on demand. The tuberous roots were harvested 12 months after planting.

Observations and measurements are focused on three agronomic and five technological traits.

\subsection{Agronomic Parameters}

\subsubsection{Incidence of Mites}

The incidence is established, six months after planting, by the ratio of the number of plants attacked by mites to the total number of plants per plot. It is expressed as a percentage.

\subsubsection{Severity of the Mites}

The severity of mites attack was scored from 1 to 5 (1: no symptoms; 2: moderate damage, no reduction in leaf area, scattered chlorotic spots on young leaves; 3 : severe chlorosis with slight reduction in leaf area; 4 : severe chlorosis and significant reduction in leaf area of young shoots; 5: very severe chlorosis and significant reduction in leaf area and young shoots, generalized defoliation) of leaves and young shoots of each clone according to the formula: 


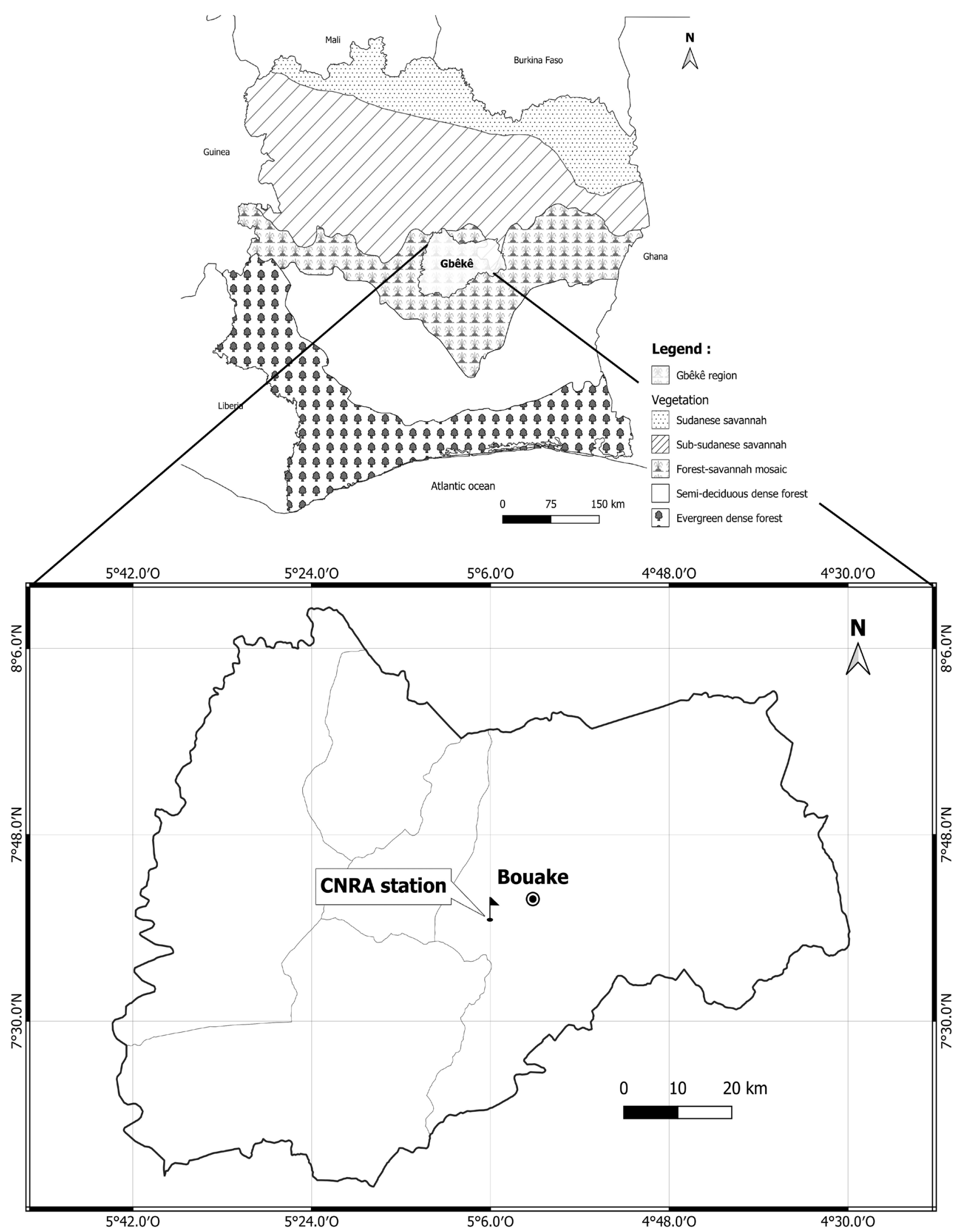

Figure 1. Location of the CNRA's Station de Recherche sur les Cultures Vivrières (SRCV) where manipulations of this study took place. 
Severity $=(\Sigma$ Number of affected plants $\times$ score $) /$ Total number of plants.

\subsubsection{Tuberous Root Yield}

At harvest time, one year after planting, the tuberous roots of each clone per plot were weighed. This determined mass was reported in $\mathrm{t} \cdot \mathrm{ha}^{-1}$.

\subsection{Technological Parameters}

\subsubsection{Dry Matter Content}

The dry matter content was determined for $200 \mathrm{~g}$ samples of tuberous roots per clone. Four tuberous roots were randomly selected, peeled and cut into small slices. These samples were placed on aluminum foil and placed in an oven at $100^{\circ} \mathrm{C}$ for 24 hours. The mass of dry matter obtained was related to the mass of fresh matter according to the formula:

Tms (\%) $=M \times 100 / 200 ; M$ : mass of the sample after drying $(\mathrm{g})$.

\subsubsection{Total Carotenoid Content}

The content was determined in the laboratory with an electronic device called iCheck Carotene. The method used is developed by IITA-iCheck ${ }^{\mathrm{rm}}$ Carotene. The test kit consists of a portable photometer and ready-to-use reagent bottles. Three tuberous roots (large, medium and small) taken at random from the total tuberous roots harvested from each clone were labelled, washed and then peeled and cut. A quantity of $5 \mathrm{~g}$ of the cut pieces were ground into a very fine paste in a porcelain mortar. Subsequently, $20 \mathrm{ml}$ of distilled water was added to the sample during the grinding in the mortar until no particles remained on the porcelain pestle. The contents were poured into a flacon and made up to $25 \mathrm{ml}$ and homogenised. Using a syringe, $0.4 \mathrm{ml}$ of the suspension was sampled and injected into the reagent flacon (iEx Carotene). The flacon was shaken and left to stand for at least $5 \mathrm{~min}$ before measurement. The flacon was inserted into the instrument and the total carotenoid content (Tct) was measured. The instrument displayed the result in $\mathrm{mg}$ carotenoids per liter $\left(\mathrm{mg} \cdot \mathrm{l}^{-1}\right)$. To obtain the Tct in $\mu \mathrm{g} \cdot \mathrm{g}^{-1}$, the displayed result was multiplied by the dilution factor $(F)$ according to the following calculation:

$$
\begin{gathered}
\text { Tct }=\text { iCheck reading } \times \text { F. Here } \mathrm{F}=62.5 \text { so we can write } \\
\text { Tct }=\text { iCheck reading } \times 62.5 \text { directly. }
\end{gathered}
$$

\subsubsection{Fiber Content}

A sample of four peeled tuberous roots from each clone was cut. A visual assessment was made by three people; the rating scales were defined as follows: 1 (no fiber), 2 (low fibrous), 3 (medium fibrous), 4 (very fibrous).

\subsubsection{Cooking and Taste}

For each clone, a sample of four peeled and cut tuberous roots was cooked in water in casseroles. After cooking, an assessment was made by three people according to a rating scale of: 1 (good), 2 (medium) and 3 (bad) for cooking and 1 (sweet), 2 (neutral), 3 (bitter) for taste. 


\subsection{Statistical Analysis}

Quantitative data (mite incidence, mite severity, yield, dry matter and total carotenoid content) were submitted to a one-way analysis of variance (ANOVA I) to test the clone effect on each trait. Before performing this test, the normal distribution according to the Shapiro-Wilk test and the homogeneity of variances were checked. When these conditions were verified and accepted, ANAOVA I was performed. Any significant ANOVA $(\mathrm{P}<0.05)$ was followed by TURKEY's highly significant difference (HSD) to rank averages. This test was used to identify objects that differed significantly from others. Data that do not follow a normal distribution according to the Shapiro-Wilk test have undergone a natural logarithm, square root and Arcsinus transformation. If the distribution remains abnormal or the variances not homogeneous after the transformations of variables, Kruskall Wallis non-parametric test was applied. Analyses were performed with Xlstat 2018.7.5 software [14]. Fiber rate, cooking and taste were scored as qualitative traits.

\section{Results}

\subsection{Agronomic Parameters}

\subsubsection{Incidence of Mites}

Mites attacked the 31 tested clones and the three control clones equally $(\mathrm{P}=0.86)$. The lowest incidence was $95 \%$ for the control Bonoua2 and the highest was 100\% for 26 clones tested and the control Bocou2.

\subsubsection{Mite Severity}

The analysis of variance of the severity was not significant $(\mathrm{P}=0.93)$. The severity of mite attack on the overall clones including controls was in the range of 3 on a 5 -point scale. The lowest severity was 2.60 for the tested clone I083594a and the highest was 3.80 obtained with the tested clone I102446 (Table 1).

\subsubsection{Tuberous Root Yield}

Estimation of fresh tuberous root yield showed highly significant variation $(\mathrm{P}<$ 0.001) among coloured flesh cassava tested clones. Of the 31 tested clones, the yield of 25 clones was statistically identical to the control variety Bocou2 (46.01 $\pm 14.88 \mathrm{t}^{\mathrm{h}} \mathrm{ha}^{-1}$ ). Five clones (I084157, I084563, I085894, I083774 and I070520) obtained at least $50 \mathrm{t} \cdot \mathrm{ha}^{-1}$ on average. The highest yield $\left(55.88 \pm 6.16 \mathrm{t} \cdot \mathrm{ha} \mathrm{a}^{-1}\right)$ was recorded with clone I083774. The lowest yield was obtained with clone I070557 $\left(16.39 \pm 5.58{\left.\mathrm{t} \cdot h \mathrm{~h}^{-1}\right)}^{-}(\right.$Table 1$)$.

\subsection{Technological Parameters}

\subsubsection{Dry Matter Content}

Dry matter content varied significantly $(\mathrm{P}<0.001)$ from $33.08 \% \pm 0.97 \%$ (clone I085006) to $43.63 \% \pm 0.61 \%$ (Bonoua2). Twenty-two clones recorded statistically identical rates with the control cultivar Yacé. The rate was at least equal to about $42 \%$ on average with coloured-flesh clones I090006, I102480 and the control 
Table 1. Averages and standard deviations of incidence, mite severity and yield of the 34 clones.

\begin{tabular}{|c|c|c|c|}
\hline Clones & Incidence of mites (\%) & Severity of mites (\%) & Yield (t.ha $\left.{ }^{-1}\right)$ \\
\hline Bocou2 (T1) & $100.00 \pm 0.00$ & $3.26 \pm 0.57$ & $46.01 \pm 14.88^{\mathrm{abcd}}$ \\
\hline Bonoua2 (T3) & $95.46 \pm 7.87$ & $3.15 \pm 0.99$ & $20.51 \pm 2.67^{\mathrm{def}}$ \\
\hline Yacé (T2) & $97.22 \pm 4.81$ & $2.94 \pm 0.50$ & $28.68 \pm 1.99^{\text {bcdef }}$ \\
\hline I082425 & $100.00 \pm 0.00$ & $3.65 \pm 0.57$ & $49.91 \pm 10.78^{\mathrm{abc}}$ \\
\hline I084157 & $98.33 \pm 2.89$ & $3.40 \pm 0.77$ & $52.18 \pm 11.60^{\mathrm{ab}}$ \\
\hline I102103 & $98.61 \pm 2.41$ & $3.18 \pm 0.96$ & $44.27 \pm 14.00^{\mathrm{abcde}}$ \\
\hline I085894 & $100.00 \pm 0.00$ & $2.89 \pm 0.30$ & $50.57 \pm 5.30^{\mathrm{abc}}$ \\
\hline I070520 & $100.00 \pm 0.00$ & $3.24 \pm 0.69$ & $52.08 \pm 16.51^{\mathrm{ab}}$ \\
\hline I102446 & $100.00 \pm 0.00$ & $3.80 \pm 0.34$ & $29.08 \pm 5.69^{\text {abcdef }}$ \\
\hline I083739 & $100.00 \pm 0.00$ & $2.90 \pm 0.59$ & $46.33 \pm 10.63^{\mathrm{abc}}$ \\
\hline I102405 & $100.00 \pm 0.00$ & $3.14 \pm 0.40$ & $31.90 \pm 4.27^{\mathrm{abcdef}}$ \\
\hline I083594b & $100.00 \pm 0.00$ & $2.81 \pm 0.45$ & $44.27 \pm 10.66^{\text {abcde }}$ \\
\hline I084563 & $100.00 \pm 0.00$ & $3.20 \pm 0.85$ & $50.46 \pm 8.92^{\mathrm{abc}}$ \\
\hline I090170 & $100.00 \pm 0.00$ & $3.23 \pm 0.37$ & $23.44 \pm 1.13^{\text {cdef }}$ \\
\hline I0701026 & $100.00 \pm 0.00$ & $3.51 \pm 0.83$ & $43.40 \pm 4.34^{\mathrm{abcdef}}$ \\
\hline I083774 & $100.00 \pm 0.00$ & $3.24 \pm 0.48$ & $55.88 \pm 6.16^{\mathrm{a}}$ \\
\hline I090091 & $100.00 \pm 0.00$ & $2.74 \pm 0.33$ & $38.84 \pm 12.38^{\text {abcdef }}$ \\
\hline I085006 & $100.00 \pm 0.00$ & $2.79 \pm 0.60$ & $47.74 \pm 12.08^{\mathrm{abcd}}$ \\
\hline I102432 & $100.00 \pm 0.00$ & $3.33 \pm 0.97$ & $40.15 \pm 8.12^{\mathrm{abcdef}}$ \\
\hline I090151 & $97.10 \pm 5.02$ & $3.09 \pm 0.85$ & $41.13 \pm 7.00^{\mathrm{abcdef}}$ \\
\hline I090111 & $100.00 \pm 0.00$ & $2.82 \pm 0.50$ & $35.92 \pm 12.37^{\text {abcdef }}$ \\
\hline I083594a & $98.61 \pm 2.41$ & $2.60 \pm 0.49$ & $39.28 \pm 3.59^{\text {abcdef }}$ \\
\hline I085613 & $100.00 \pm 0.00$ & $2.68 \pm 0.44$ & $45.47 \pm 4.37^{\mathrm{abcd}}$ \\
\hline I102429 & $100.00 \pm 0.00$ & $3.57 \pm 1.02$ & $41.78 \pm 3.42^{\mathrm{abcdef}}$ \\
\hline I082264 & $100.00 \pm 0.00$ & $3.15 \pm 0.78$ & $45.79 \pm 6.96^{\mathrm{abcd}}$ \\
\hline I090090 & $100.00 \pm 0.00$ & $3.18 \pm 0.53$ & $33.75 \pm 8.11^{\text {abcdef }}$ \\
\hline I082461 & $100.00 \pm 0.00$ & $3.28 \pm 0.39$ & $37.98 \pm 2.09^{\mathrm{abcdef}}$ \\
\hline I090006 & $100.00 \pm 0.00$ & $3.54 \pm 0.83$ & $36.13 \pm 7.05^{\text {abcdef }}$ \\
\hline I102480 & $100.00 \pm 0.00$ & $3.33 \pm 0.69$ & $27.24 \pm 10.04^{\text {bcdef }}$ \\
\hline I083849 & $98.61 \pm 2.41$ & $2.90 \pm 0.32$ & $32.12 \pm 10.38^{\text {abcdef }}$ \\
\hline I083724b & $100.00 \pm 0.00$ & $3.02 \pm 0.80$ & $27.78 \pm 5.87^{\text {bcdef }}$ \\
\hline I083724a & $100.00 \pm 0.00$ & $3.25 \pm 0.54$ & $17.58 \pm 4.56^{\mathrm{ef}}$ \\
\hline I085056 & $100.00 \pm 0.00$ & $3.51 \pm 0.89$ & $26.26 \pm 2.71^{\text {bcdef }}$ \\
\hline I070557 & $100.00 \pm 0.00$ & $2.68 \pm 0.55$ & $16.39 \pm 5.58^{\mathrm{f}}$ \\
\hline Overall average & $99.53 \pm 1.95$ & $3.15 \pm 0.62$ & $38.24 \pm 12.46$ \\
\hline P-value & 0.86 & 0.93 & $<0.001$ \\
\hline
\end{tabular}

In the same column, values followed by the same letters are statistically identical at the $5 \%$ level. T1: Control for yield; T2: Control for dry matter content; T3: Control for fiber content, cooking and taste after cooking. 
Yacé. However, the highest rate was recorded with the control Bonoua2 with a relatively higher rate than the reference control Yacé. The lowest rate was obtained with clone 1085006 (Table 2).

\subsubsection{Total Carotenoids Content}

Total carotenoids content in tuberous roots was very highly significant different $(\mathrm{P}<0.001)$ among coloured-flesh clones and among these clones and the improved control variety Bocou2 (Table 2). Thirteen clones (I082425, I084157, I102446, I102405, I083594b, I090170, I0701026, I090091, I085006, I102432, I090111, I083594a and I090090) recorded statistically significantly higher levels than the control Bocou2 $\left(8.01 \pm 0.19 \mu \mathrm{g} \cdot \mathrm{g}^{-1}\right)$. The levels recorded with the 31 ITTA clones and Bocou2 (yellow-flesh) were higher than those of the local varieties Bonoua2 and Yacé (white-flesh). The highest total carotenoid content was recorded with clone I082425 $\left(18.39 \pm 1.19 \mu \mathrm{g} \cdot \mathrm{g}^{-1}\right)$ which is statistically identical to those of clones I082425, I084157, I102446 and I090091 and the lowest content with Yacé $\left(3.48 \pm 0.168 \mu \mathrm{g} \cdot \mathrm{g}^{-1}\right)$.

\subsubsection{Fiber Content}

Fiber ratio varied from 1 to 4 . The score 1 (no fiber) was obtained with the control Bonoua2. The tuberous roots of the 31 coloured-flesh clones were fibrous (low to very fibrous). Thirteen clones (I084157, I070520, I083739, I0701026, I083774, I085006, I102429, I082461, I090006, I102480, I083724b, I083724a and I085056) were low fibrous with a score of 2. Fifteen clones (I102103, I085894, I102446, I102405, I102405, I084563, I090170，I090091，I102432，I090151, I090111, I083594a, I085613, I083849 and I070557) were moderately fibrous with score 3 and three clones (I082425, I082264 and I090090) were highly fibrous with score 4 .

\subsubsection{Cooking}

Only the clone I090006 obtained with the control Bonoua2 a score of 1, i.e. good cooking. Thirteen clones (I084157, I0701026, I083774, I085006, I102432, I085613, I082264, I090090, I082461, I102480, I083724b, I083724a and I085056) were medium cooking (score 2) and seventeen clones (I082425, I102103, I085894, I070520, I102446, I083739, I102405, I102405, I084563, I090170, I090091, I090151, I090111, I083594a, I102429, I083849 and I070557) were bad cooking (score 3).

\subsubsection{Taste}

Seven clones (I082425, I070520, I083774, I082264, I083849, I085056 and I070557) with coloured-flesh and the control Bonoua2 obtained a score of 1, i.e. good taste. Twenty clones (I084157, I085894, I102446, I102405, I102405, I084563, I0701026，I090091，I085006，I102432，I090151，I083594a，I085613，I102429, I090090, I082461, I090006, I102480, I083724b and I083724a) were neutral taste (note 2) and four clones (I102103, I083739, I090170 and I090111) were bitter (note 3). 
Table 2. Mean values and standard deviation of dry matter content and total carotenoids content of the 34 cassava clones

\begin{tabular}{|c|c|c|}
\hline Clones & Dry matter content (\%) & Total carotenoid content $\left(\mu \mathrm{g} \cdot \mathrm{g}^{-1}\right)$ \\
\hline Bocou2 (T1) & $41.43 \pm 0.23^{\mathrm{abcd}}$ & $8.01 \pm 0.19^{\mathrm{gh}}$ \\
\hline Bonoua2 (T3) & $43.63 \pm 0.61^{\mathrm{a}}$ & $3.87 \pm 0.34^{\mathrm{h}}$ \\
\hline Yacé (T2) & $42.70 \pm 1.12^{\mathrm{ab}}$ & $3.48 \pm 0.17^{\mathrm{h}}$ \\
\hline I082425 & $35.97 \pm 0.43^{\text {cdef }}$ & $18.39 \pm 1.19^{\mathrm{a}}$ \\
\hline I084157 & $37.48 \pm 5.38^{\mathrm{abcdef}}$ & $17.57 \pm 1.92^{\mathrm{ab}}$ \\
\hline I102103 & $35.76 \pm 2.55^{\text {cdef }}$ & $12.93 \pm 0.95^{\text {abcdefg }}$ \\
\hline I085894 & $37.38 \pm 0.72^{\mathrm{abcdef}}$ & $12.78 \pm 0.65^{\text {bcdefg }}$ \\
\hline I070520 & $35.63 \pm 5.31^{\text {cdef }}$ & $13.57 \pm 1.32^{\text {abcdefg }}$ \\
\hline I102446 & $37.34 \pm 2.70^{\mathrm{abcdef}}$ & $16.26 \pm 0.55^{\mathrm{abc}}$ \\
\hline I083739 & $37.38 \pm 0.72^{\mathrm{abcdef}}$ & $12.89 \pm 0.09^{\text {abcdefg }}$ \\
\hline I102405 & $39.92 \pm 1.70^{\text {abcde }}$ & $15.02 \pm 0.59^{\text {abcde }}$ \\
\hline I083594b & $37.26 \pm 1.26^{\mathrm{abcdef}}$ & $14.80 \pm 1.60^{\mathrm{abcde}}$ \\
\hline I084563 & $34.05 \pm 0.91^{\mathrm{ef}}$ & $12.88 \pm 2.21^{\mathrm{abcdefg}}$ \\
\hline I090170 & $37.18 \pm 0.91^{\text {abcdef }}$ & $14.96 \pm 1.60^{\mathrm{abcde}}$ \\
\hline I0701026 & $38.33 \pm 0.54^{\mathrm{abcdef}}$ & $14.35 \pm 0.22^{\mathrm{abcde}}$ \\
\hline I083774 & $41.97 \pm 1.79^{\mathrm{abcd}}$ & $9.91 \pm 0.04^{\mathrm{defg}}$ \\
\hline I090091 & $35.91 \pm 2.20^{\text {cdef }}$ & $16.29 \pm 1.79^{\mathrm{abc}}$ \\
\hline I085006 & $33.08 \pm 0.97^{\mathrm{f}}$ & $15.45 \pm 1.74^{\mathrm{abcd}}$ \\
\hline I102432 & $35.61 \pm 0.97^{\text {def }}$ & $14.84 \pm 2.42^{\mathrm{abcde}}$ \\
\hline I090151 & $41.06 \pm 0.86^{\mathrm{abcd}}$ & $13.37 \pm 0.42^{\text {abcdefg }}$ \\
\hline I090111 & $33.83 \pm 1.18^{\mathrm{ef}}$ & $13.73 \pm 0.61^{\mathrm{abcdef}}$ \\
\hline I083594a & $38.44 \pm 0.02^{\mathrm{abcdef}}$ & $13.60 \pm 1.80^{\text {abcdef }}$ \\
\hline I085613 & $39.18 \pm 2.12^{\mathrm{abcdef}}$ & $9.67 \pm 1.12^{\mathrm{efg}}$ \\
\hline I102429 & $36.36 \pm 4.16^{\text {bcdef }}$ & $13.36 \pm 2.11^{\text {abcdefg }}$ \\
\hline I082264 & $37.45 \pm 1.78^{\mathrm{abcdef}}$ & $12.12 \pm 0.73^{\text {bcdefg }}$ \\
\hline I090090 & $39.65 \pm 0.87^{\text {abcde }}$ & $14.23 \pm 1.50^{\mathrm{abcdef}}$ \\
\hline I082461 & $40.66 \pm 1.45^{\mathrm{abcd}}$ & $11.18 \pm 0.42^{\text {cdefg }}$ \\
\hline I090006 & $42.67 \pm 1.31^{\mathrm{ab}}$ & $12.35 \pm 0.67^{\text {bcdefg }}$ \\
\hline I102480 & $42.12 \pm 0.76^{\mathrm{abc}}$ & $8.68 \pm 1.73^{\mathrm{gh}}$ \\
\hline I083849 & $36.05 \pm 2.05^{\text {cdef }}$ & $12.78 \pm 1.30^{\text {bcdefg }}$ \\
\hline I083724b & $40.70 \pm 1.11^{\mathrm{abcd}}$ & $12.06 \pm 0.87^{\text {bcdefg }}$ \\
\hline I083724a & $41.21 \pm 0.68^{\mathrm{abcd}}$ & $11.64 \pm 0.69^{\text {cdefg }}$ \\
\hline I085056 & $39.86 \pm 1.17^{\mathrm{abcd}}$ & $11.24 \pm 2.50^{\text {cdefg }}$ \\
\hline I070557 & $40.97 \pm 1.86^{\mathrm{abcd}}$ & $10.51 \pm 1.60^{\operatorname{defg}}$ \\
\hline Overall Average & $38.48 \pm 3.22$ & $12.61 \pm 3.35$ \\
\hline P-value & $<0.001$ & $<0.001$ \\
\hline
\end{tabular}

In the same column, values followed by the same letters are statistically identical at the $5 \%$ level. T1: Control for yield; T2: Control for dry matter content; T3: Control for fiber content, cooking and taste after cooking. 


\section{Discussion}

\subsection{Agronomic Parameters}

The tropical zone offers favorable conditions for the most damaging mite species Mononychellus tanajoa on cassava during the dry season when mean temperatures vary between $24^{\circ} \mathrm{C}$ and $31^{\circ} \mathrm{C}$ and relative humidity values from $50 \%$ to $70 \%$ [15]. The 31 cassava coloured-flesh clones showed significant attacks as observed by [16] cited by [5] who showed that the selection of mite resistant varieties is less efficient. So, to control these attacks, the use of natural predators seems to be the most efficient method. Indeed, [16] noted that mites belonging to the family Phytoseiidae are used as the main control agents against green mites. Biological control programs already exist in some research institutes such as IITA, CIAT and EMBRAPA.

High variability in cassava yield was observed among the 31 tested clones. Differences in fresh tuberous root yields among clones were observed. This difference could be explained firstly by the number of roots per plant and, on the other hand, by the weight of tuberous roots per plant. In our study, five colouredflesh clones had yields of at least $50 \mathrm{t} \cdot \mathrm{ha}^{-1}$. These yields are higher than those recorded by [10] during the evaluation work, in which the best performing clones had yields below $40 \mathrm{t} \cdot \mathrm{ha}^{-1}$. However, these yields are close (or even statistically identical) to the yields obtained by [9] which were around $60 \mathrm{t} \cdot \mathrm{ha}^{-1}$ in an evaluation of coloured-flesh cassava varieties. Of the 31 coloured-flesh clones, 25 clones gave fresh tuberous root yields statistically equivalent to Bocou2 (reference control, a variety popularized in Côte d'Ivoire) which is an improved yellow-flesh, high-yielding variety. The results obtained in this study could be improved by efficient pest and disease control. Local varieties Bonoua2 and Yacé are not very productive compared to some clones that are improved varieties. These results are in agreement with [11] [17] [18] and [19] which showed the superiority of yields of improved varieties over local varieties, in other words, improved varieties give significantly higher yields than local varieties. According to [17], this situation can be explained by the recurrent selection practiced at IITA, transmitting interesting agronomic traits from previously selected high-yielding progenitors into the new varieties.

\subsection{Technological Parameters}

The dry matter content varied from $33.08 \%$ to $43.63 \%$ with a very highly significant difference. This is in agreement with [18] who observed highly significant differences among the dry matter rates of several improved clones. This difference can be explained by the fact that clones belong to different genotypes. The dry matter content of some coloured-flesh tested clones are comparable to those obtained by [9] and [10] which are in the range of 30\% - 40\% in a performance evaluation study of coloured-flesh cassava clones compared to white-flesh cassava varieties which obtained higher levels. Indeed, dry matter content is negatively correlated to total carotenoids content as reported by several authors in- 
cluding [20] and [21]. However, two yellow-flesh varieties (I090006 and I102480) have similar dry matter content as Yacé, the white-flesh control.

The 31 coloured-flesh clones and the control Bocou2, which is a yellow-flesh variety, had higher total carotenoid contents than the local white-flesh varieties Bonoua2 and Yacé. These results support those of [22] who showed that coloured-flesh cassava varieties have higher total carotenoid contents than whiteflesh varieties. Tested clones recorded higher total carotenoid contents than the control Bocou2 $\left(8.01 \pm 0.19 \mu \mathrm{g} \cdot \mathrm{g}^{-1}\right)$. Clones I082425 and I084157 recorded the highest total carotenoids contents of $18.39 \mu \mathrm{g} \cdot \mathrm{g}^{-1}$ and $17.57 \mu \mathrm{g} \cdot \mathrm{g}^{-1}$ respectively, which is more than twofold the content of the control $\left(8.01 \mu \mathrm{g} \cdot \mathrm{g}^{-1}\right)$. This could be explained by the fact that these clones have been enriched (biofortified) in carotenoids. Howerver, the highest carotenoid contents in tested clones are far lower than those observed in coloured-flesh sweet potato varieties, which range from $20 \mu \mathrm{g} \cdot \mathrm{g}^{-1}$ to more than $100 \mu \mathrm{g} \cdot \mathrm{g}^{-1}$ [23], but much higher than those observed in coloured-flesh cassava varieties, which range from $0.31 \mu \mathrm{g} \cdot \mathrm{g}^{-1}$ to 10.5 $\mu \mathrm{g} \cdot \mathrm{g}^{-1}[24]$.

Coloured-flesh clones had generally bad cooking, in accordance with [25] cited by [26] and [27]. These authors showed that bad cooking of coloured-flesh cassava could be due to high carotenoid content. It could also be due to the quality of the starch i.e. the level of cooking resistant starch which could be high. Indeed, [28] found high levels of starch qualified as cooking resistant in bananas that did not cook. On the other hand, low-fiber clones could be suitable for other purposes (semolina, gari etc.).

Bad tastes are due to the content of cyanogenic glycosides that define the bitterness of cassava flesh [3]. Cassava is considered 'bitter', when the cyanogenic glucoside content is higher than $50 \mu \mathrm{g} \cdot \mathrm{g}^{-1}$ of fresh matter. For bitter cassava varieties, transformation processes for the detoxification of cassava are necessary in order to make it fit for consumption. Indeed, the ingesting of large quantities of uncooked or boiled bitter roots for a very short time can be dangerous because cyanogenic glycosides can be broken down by the enzymes of the intestinal flora and release hydrocyanic acid (HCN) that is toxic to the human body [3].

\section{Conclusion}

The aim was to identify high-yielding, carotenoid-rich and versatile cassava varieties by comparing 31 coloured cassava clones with three control clones. Several clones were identified according to yield, dry matter content and total carotenoid contents. Coloured-flesh Cassava was generally fibrous, with bad cooking and good taste after cooking in water. The clone I082425 had the highest total carotenoid content with high yield, medium dry matter content, good taste, but bad cooking. The clone I084157 had the highest total carotenoid content and yield, low fiber content, high dry matter content, medium cooking and neutral taste. In addition, clone I083774 is also interesting (high yield, dry matter content close to the reference control, medium cooking and good taste, but with half 
the total carotenoid content of the best clone). The introduction of these three identified clones in the farming environment can therefore strengthen food security with various food transformations.

\section{Conflicts of Interest}

The authors declare no conflicts of interest regarding the publication of this paper.

\section{References}

[1] Food and Agriculture Organization Corporate Statistical Database (FAOSTAT) (2020). http://www.fao.org/faostat/fr/\#data/QC

[2] Segnou, M. (2000) Caractéristiques morpho-physiologiques liées à la précocité du rendement chez le manioc. Cahiers Agricultures, 9, 77-79.

[3] Vernier, P., N’Zué, B. and Zakhia-Rozis, N. (2018) Le manioc, entre culture alimentaire et filière agro-industrielle. Éditions Quae, CTA, Presses agronomiques de Gembloux.

[4] Salvador, E.M., Steenkamp, V. and Mccrindle, C.M.E. (2014) Production, Consumption and Nutritional Value of Cassava (Manihot esculenta Crantz) in Mozambique: An Overview. Journal of Agricultural Biotechnology and Sustainable Development, 6, 29-38. https://doi.org/10.5897/JABSD2014.0224

[5] N’Zué, B. (2007) Caractérisation morphologique, sélection variétale et amélioration du taux de multiplication végétative chez le manioc (Manihot esculenta Crantz (Euphorbiaceae). Ph.D. Dissertation, Université de Cocody, Abidjan.

[6] Mendez del Villar, P., Adaye, A., Tran, T., Allagba, K. and Bancal, V. (2017) Analyse de la chaîne de Manioc en Côte d'Ivoire. Rapport pour l'Union Européenne, DG-DEVCO. Value Chain Analysis for Development Project (VCA4D CTR 2016/ 375-804), Côte d'Ivoire, 169 p.

[7] Gannon, B.M., Pungarcher, I., Mourao, L., Davis, C.R., Simon, P., Pixley, K.V. and Tanumihardjo, S. A. (2016) ${ }^{13} \mathrm{C}$ Natural Abundance of Serum Retinol Is a Novel Biomarker for Evaluating Provitamin A Carotenoid-Biofortified Maize Consumption in Male Mongolian Gerbils. The Journal of Nutrition, 146, 1290-1297. https://doi.org/10.3945/jn.116.230300

[8] Ceballos, H., Davrieux, F., Talsma, E.F., Belalcazar, J., Chavarriaga, P. and Andersson, M.S. (2017) Carotenoids in Cassava Roots. In: Cvetkovic, D. and Nikolic, G., Eds., Carotenoids, IntechOpen, London, 189-221.

https://doi.org/10.5772/intechopen.68279

[9] Ntawuruhunga, P. and Okidi, J. (2010) Eastern Africa Root Crops Research Network (EARRNET) Legacy. Performance Report No. 20042007, International Institute of Tropical Agriculture, Ibadan.

[10] Dixon, A., Okechukwu, R.U., Akoroda, M.O., Ilona, P., Ogbe, F., Eges, C.N., Kulakow, P.A., Ssemakula, G., Maziya-Dixon, B. and Iluebbey, P. (2010) Improved Cassava Variety Handbook. Rapport Technique, International Institute of Tropical Agriculture, Ibadan.

[11] Djinadou, A.K.A., Olodo, N.I. and Adjanohoun, A. (2018) Evaluation du comportement de variétés améliorées de manioc riches en bêta-carotène au Sud du Bénin. International Journal of Biological and Chemical Sciences, 12, 703-715. https://doi.org/10.4314/ijbcs.v12i2.8 
[12] Traoré, K., Sorho, F., Dramane, D.D. and Sylla, M. (2013) Adventices hôtes alternatifs de virus en culture de Solanaceae en Côte d'Ivoire. Agronomie Africaine, 25, 231 237.

[13] Fondio, L., Djidji, H.A., Kouamé, C. and Traoré, D. (2003) Effet de la date de semis sur la production du gombo (Abelmoschus spp.) dans le centre de la Côte d'Ivoire. Agronomie africaine, 15, 13-27. https://doi.org/10.4314/aga.v15i1.1626

[14] XLSTAT by Addinsoft (2018) Statistical and Data Analysis Solution Version 2018.7.5. https://www.xlstat.com

[15] Campo, B.V.H., Hyman, G. and Bellotti, A. (2011) Threats to Cassava Production: Known and Potential Geographic Distribution of Four Key Biotic Constraints. Food Security, 3, Article No. 329. https://doi.org/10.1007/s12571-011-0141-4

[16] Ikotun, T. and Osiru, D.S.O. (1990) Les contraintes à la production. Porceedings Le manioc en Afrique. Tropicale, International Institute of Tropical Agriculture (IITA), Ibadan, 1-13.

[17] N'Zué, B., Zouhouri, P.G. and Sangaré A. (2004) Performances agronomiques de quelques variétés de Manioc (Manihot esculenta Crantz) dans trois zones agroclimatiques de la Côte d'Ivoire. Agronomie africaine, 16, 1-7.

https://doi.org/10.4314/aga.v16i2.1646

[18] Bakayoko, S., Kouadio, K.K.H., Soro, D., Tschannen, A., Nindjin, C., Dao, D. and Girardin, O. (2012) Rendements en tubercules frais et teneurs en matière sèche de soixante-dix nouvelles variétés de manioc (Manihot esculenta Crantz) cultivées dans le centre de la Côte d'Ivoire. Journal of Animal \& Plant Sciences, 14, 1961-1977.

[19] Kouadio, K.K.H., Ettien, D.J.B., Bakayoko, S., Soro, D. and Girardin, O. (2014) Variabilité physico-morphologique des racines tubéreuses de manioc (Manihot esculenta Crantz) cultivées sur ferralsol en zone de forêt d'Afrique de l'Ouest. Journal of Applied Biosciences, 82, 7316-7325. https://doi.org/10.4314/jab.v82i1.1

[20] Akinwale, M.G.B., Aladesanwa, R.D., Akinyele, B.O., Dixon, A.G.O. and Odiyi, A.C. (2010) Inheritance of $ß$-Carotene in Cassava (Manihot esculenta Crantz). International Journal of Genetics and Molecular Biology, 2, 198-201.

[21] Ceballos, H., Morante, N., Sánchez, T., Ortiz, D., Aragon, I., Chávez, A.L., Pizarro, M., Calle, F. and Dufour, D. (2013) Rapid Cycling Recurrent Selection for Increased Carotenoids Content in Cassava Roots. Crop Science, 53, 2342-2351. https://doi.org/10.2135/cropsci2013.02.0123

[22] Bechoff, A., Chijioke, U., Tomlins, K.I., Govinden, P., Ilona, P., Westby, A. and Boy, E. (2015) Carotenoid Stability during Storage of Yellow Gari Made from Biofortified Cassava or with Palm Oil. Journal of Food Composition and Analysis, 44, 36-44. https://doi.org/10.1016/j.jfca.2015.06.002

[23] Kapinga, R.S., Tumwegamire, S., Ndunguru, J., Andrade, M.I., Agili, S. and Mwanga, R.O.M. (2010) Catalogue of Orange-Fleshed Sweetpotato Varieties for Sub-Saharan Africa. International Potato Center, Lima.

[24] Vimala, B., Thushara, R. and Nambisan, B. (2010) Carotenoid Retention in Yellow-Fleshed Cassava during Processing. Proceedings of the 15th Triennial International Society for Tropical Root Crops (ISTRC) Symposium, Lima, 2-6 November 2009, 24-26.

[25] Moorthy, S.N., Wenham, J.E. and Blanshard, J.M. (1996) Effect of Solvent Extraction on the Gelatinisation Properties of Flour and Starch of Five Cassava Varieties. Journal of the Science of Food and Agriculture, 72, 329-336. https://doi.org/10.1002/(SICI)1097-0010(199611)72:3\%3C329::AID-ISFA663\%3E3. $\underline{0 . \mathrm{CO} ; 2-1}$ 
[26] Njenga, P., Edema, R. and Kamau, J. (2014) Combining Ability for Beta-Carotene and Important Quantitative Traits in a Cassava F1 Population. Journal of Plant Breeding and Crop Science, 6, 24-30. https://doi.org/10.5897/JPBCS12.069

[27] Vimala, B., Nambisan, B., Thushara, R. and Unnikrishnan, M. (2008) Variability of Carotenoids in Yellow-Fleshed Cassava (Manihot esculenta Crantz) Clones. Central Tuber Crops Research Institute, Kerala.

[28] Toro, A.G. (2015) Impact de l'opération de cuisson du plantain sur la digestibilité in vitro de l'amidon. Ph.D. Dissertation, SupAgro, Monpellier. 